\title{
Student Counsellors' Perception on Initiating Bibliotherapy Service in the University Environment
}

Sajeewanie D. Somaratna ${ }^{1}$

\begin{abstract}
Bibliotherapy or use of books and literature related activities as a therapeutic method or counselling method to address students' specific issues is being practiced in several universities in developed countries all over the world. However, there is little evidence from the Sri Lankan scenario. Hence, this study aims to find the university student counsellors' perception on initiating bibliotherapy service in the university environment as a counseling tool. Structured interviews and a questionnaire survey were conducted using student counsellors at the University of Colombo to check their views on bibliotherapy service. Forty two counsellors responded, representing faculties of Arts, Education, Library, Management, Medical, and the Science, with response rate of $65.63 \%$. Uncertainty about careers and study directions $(63.64 \%)$, difficulties in motivation or decision making $(36.36 \%)$, and exam stress and anxiety (34.09\%) are the most prominent issues of university students those were brought to the counselors who practiced short-term individual counselling method, followed by workshops and long term group counselling. Only $2.38 \%$ of the counsellors are
\end{abstract}

\footnotetext{
${ }^{1}$ Senior Assistant Librarian, Faculty of Science, University of Colombo. Email: sajees@lib.cmb.ac.lk (D) https://orcid.org/0000-0003-1128-1330 
practicing bibliotherapy techniques in combination with other counselling methods. Six student counsellors were able to define the term 'bibliotherapy' and had a clear understanding of the method. After having a proper understanding of the bibliotherapy service, all the counsellors believe that bibliotherapy service would help overcome the student issues such as 'difficulties with English language skills', 'uncertainty about careers and study directions', 'exam stress and anxiety', and 'difficulties in motivation or decision making' but may not succeed in grief, trauma/loss, specific clinical diagnoses, abuse and substance. 67\% of the counsellors identify university library as the most suitable place to develop the collection and self-help materials, work books, poetry, fiction, non-fiction, audio books, audiovisual books, and e-books as the suggested material types. The main selection criteria for developing a bibliotherapy collection are based on the recommendation made by student counsellors. 'Acquisition of knowledge by diverse people in culture, situations, abilities, experiences, and perspectives' is identified as the most prominent benefit of bibliotherapy service. Possible challenges also were discussed. Active involvement of the university librarians collaborating with the student counsellors of the university is essential to initiate and continue this service and proper support from the higher authorities of the university is recommended.

Keywords: Bibliotherapy, Student Counsellors, Perception, University Library, Librarians 


\section{Introduction}

Book has been used for therapeutic purposes since the early Greeks time and is known as a therapeutic tool since 1900s (Riahinia \& Azimi, 2007) and bibliotherapy is the use of literature to promote healing among emotionally and socially disturbed groups. Nearly 100 years ago, Samuel Crothers (1916) first coined the term 'bibliotherapy' which is defined as treatment through books. The word "bibliotherapy" is made up of two parts: biblion meaning "book" and therapia meaning "to cure" and altogether means "to cure by means of books". Bibliotherapy has been referred by many names, including 'bibliocounseling', 'biblioeducation', 'bibliopsychology', 'library therapeutics', and 'literatherapy' (Ogrenir, 2013). It arises from the concept that reading can affect an individual's attitude and behavior and is thus an important tool for modifying the values. Bibliotherapy can also include the guided reading of written materials to help the reader grow in self-awareness (Harris \& Hodges, 1995).

University students all over the world, come across different issues related to mental, social, family, education, etc. Creating a suitable learning environment by solving their specific issues is one of the main intents of any university. Proper guidance and support through counselling are practicing in the education sector throughout the world to ensure good mental health of the students. In Sri Lanka too, schools, universities, and higher education institutions are engaging in the counselling service. In the university sector of Sri Lanka, permanent academic staff members are voluntarily involved in this service in the saint of depressed students. Both the permanent and temporary student counsellors are appointed from the academic staff in each university and 
their work is coordinated by the student counsellors' office. Student counsellors are trained to address different student issues and most of the students are benefited from this service. These counsellors help students to overcome from common mental issues such as education matters, language barriers, career issues, family issues, and personality issues to specific mental issues such as grievance, addiction, suicide, abuse, and trauma. Specific student issues requiring professional psychiatric support are forwarded to professional student counselors or psychiatrists for further treatment. With the developments of the publishing sector in the world in both printed and digital formats, it is easy to find guided reading material to address common issues of university students. There is evidence from universities around the world on guided reading for specific mental issues or bibliotherapy service but a little evidence from the Sri Lankan scenario. Therefore, it is important to implement such a valuable service through the university library in collaboration with the student counsellors of the university. Most of the university students will be benefited from this service and on the other hand, this will help student counselors to guide them through a proper framework. Hence, this study aims to identify student counsellors' perceptions on initiating bibliotherapy service in the university environment with special reference to the Unversity of Colombo. To achieve the aim following objectives are set.

\section{Objectives}

1. To identify prevailing student counselling practices at the university environment

2. To identify student counsellors' perception of bibliotherapy as a counselling method 
3. To find out a mechanism to develop a bibliotherapy service in the university

4. To discover possible challenges when implementing the bibliotherapy service

\section{Research Questions}

1. What are the experiences of student counsellors on different student issues and counselling methods?

2. What is the current understanding of student counsellors on bibliotherapy techniques?

3. What are the student counsellors' perceptions on applying bibliotherapy service to solve students' issues?

4. What are the concerns when developing a bibliotherapy service in the university?

5. What are the benefits of the "bibliotherapy" service for university students?

6. What are the possible challenges when implementing the bibliotherapy service?

\section{Literature Review}

In modern science "bibliotherapy" is defined as a process that facilitates personal development or problem resolution through the reading of books including both fiction and nonfiction materials which are widely used by various helpers to address common developmental or situational issues (developmental bibliotherapy) as well as more serious mental health problems (clinical bibliotherapy) (McMillen \& Pehrsson, 2004). Developmental bibliotherapy is used in educational settings whereas clinical bibliotherapy works toward specific mental health goals 
(McMillen \& Pehrsson, 2004). Another categorization found in literature as explained by McMillen and Pehrsson is reading bibliotherapy and interactive bibliotherapy where reading bibliotherapy means self reading without further discussions and interactive bibliotherapy leads discussions after reading.

Bibliotherapy is practiced by a variety of professions all around the world including medical professionals, counsellors, and librarians. In a review of the literature, Forrest (1998) showed that bibliotherapy is practiced foremost by psychologists (57\%), followed by librarians (20\%), nurses (11\%), and social workers (10\%) (Riahinia \& Azimi, 2011). Forrest (1998) showed that the librarians are the second most active implementers of bibliotherapy: in fact, their role in bibliotherapy is critical (Crumley, 2006), especially when they select readings for bibliotherapy purposes. With good knowledge of relevant published materials, they can select readings to help users with mental, emotional, domestic, and social problems. In Western countries, bibliotherapy has been widely recognized and this service holds great promise in helping people to better address concerns of negative emotion and personal development (Sheih \& Hunng, 2013).

There is strong evidence to suggest that books can be effective as a form of self-help and collections have been chosen by both healthcare professionals and readers who have benefited from them. Emotional and academic difficulties can be a common part of university life and these collections provide information and support for dealing with a wide range of issues such as depression, anxiety, panic, building self-confidence, and assertiveness. It also offers several books on topics relating, specifically to the university experience such as giving presentations, managing exam 
stress, or coping with life away from home. Heath et al. (2005), discuss storytelling related to bibliotherapy by emphasizing the catalytic power of the stories for change and opportunities for children to gain insight and healthier ways to face difficulties.

Reviews of the literature (McMillen \& Pehrsson, 2004) suggest that numerous positive outcomes may result from bibliotherapy, including but not limited to the following: increasing self-awareness; enhancing empathetic understanding and knowledge of other cultures; fostering an appreciation of one's own ethnic/cultural identity; clarifying emerging values; stimulating discussion of feelings, thoughts, and behaviors; improving coping skills and generating ideas for problem solving; and alleviating negative emotions such as stress, anxiety, and loneliness (Pardeck \& Pardeck, 1998).

Bibliotherapy technique of counselling has been widely recognized in the world and this service holds great promise in helping people to better address concerns of negative emotion and personal development. Bibliotherapeutic services are being practiced in several universities in the world, especially in developed countries, but a few studies from the Sri Lankan scenario. Arulanantham and Navaneethakrishnan (2014a) reviewed the bibliotherapy technique in Higher Education in Sri Lanka and its implication through university libraries. Accordingly, bibliotherapy service can be implemented by university libraries by creating 'Bibliotherapy Corner' in the library, and also students with special needs can be addressed by this service. Further, they suggest having a policy decision at the national level under the direction of SCOLIS (Standing Committee of Library and Information Science), University Grants Commission in the collaboration with 
University Librarians Association Sri Lanka based on international standards and recommendations. The study on implementing bibliotherapy through public libraries in Jaffna District, Sri Lanka, identifies public librarians' awareness of the bibliotherapy service and their characteristics as bibliotherapists. It proposed this service helped develop the mental and social conditions of post-war community in the Jaffna District (Arulanantham \& Navaneethakrishnan, 2014b). The proposed concept by Premarathne (2016) is expected to survey students who are seeking student counsellors' help through the health centre, career guidance unit, and the student counselling centre at the University of Peradeniya. He expected students to benefit from this service to reduce negative emotions such as stress, anxiety, and loneliness while enhancing interpersonal skills, self-esteem, self-awareness, and emotional maturity. According to the reviewed literature majority of the studies are focused on librarians' and students' perception of bibliotherapy but not student counsellors' perception, the group who are directly involved in student counselling in universities. Therefore, there is a significant gap in literature on student counsellors' perception and collaboration in initiating bibliotherapy service in the universities and this paper will certainly minimize it.

\section{Methodology}

Structured interviews and a questionnaire survey were conducted using the student counsellors at the University of Colombo to obtain their views on bibliotherapy as a counseling tool from June to August 2019. The total student counsellor population is 64 except the affiliated institutions and they are distributed in different faculties of the university. Interviews were conducted with selected student counsellors and 
questionnaires were distributed among the rest of the counsellors. 42 responded, covering faculties of Science, Education, Arts, Management, Medical, Law and the Library and the response rate is $65.63 \%$.

\section{Framework for the Structured Interview/Questionnaire Development}

The framework for the structured interviews included four main sections except for the background information.

\section{Part 1}

Affiliated faculty of the student counsellor, their experience in counselling, current practices of counselling and understanding of the bibliotherapy technique were included in Part 1.

Definition of the "bibliotherapy" was included in between Part 1 and Part 2 of the questionnaire to help proceed to the Part 2 with a proper understanding of the technique.

\section{Definition:}

"Bibliotherapy" is a term used to describe the use of books to help people understand and cope with emotional, psychological, social and/or academic issues. 'Biblio' is the Greek word for books and 'therapy' comes from therapeia meaning 'to help medically'.

Working definition based onSamuel Crothers (1916)

\section{Part 2}

Student counsellors perception on the acceptability of 11 criteria on the purpose of the bibliotherapy was included and counsellors were asked to rate them on 5 points Likert scale where $5=$ Strongly Agree, $4=$ Agree, 3= Neither Agree nor Disagree, 2= Disagree and 1= Strongly Disagree. 


\section{Part 3}

Criteria to consider when developing a plan for the bibliotherapy service within the University environment was included in Part 3 and it included 4 sub sections: identifying a place to develop the collection, method of selecting reading material for the collection, methods of practicing the bibliotherapy technique and identifying main subject headings to build up the collection. 5 points Likert scale was used to obtain the counselors' opinions where 5=Strongly Agree, 4= Agree, 3= Neither Agree nor Disagree, 2= Disagree, and 1= Strongly Disagree.

\section{Part 4}

Expected benefits for students from the bibliotherapy service were added in Part 4 and used five points Likert scale to collect information. Two open-ended questions were included to check open views of the counsellors on this service and to identify possible challenges for implementing the service. Both qualitative and quantitative methods were used to analyze data and MS Excel 2013 and IBM SPSS software were used for the quantitative analysis.

\section{Results and Discussion}

Sixty-four student counsellors were distributed among seven faculties of the University of Colombo, and forty-two responded to the questionnaires and interviews. The response rate was $65.63 \%$. Among the counsellors, three were senior student counselors of the university, four were permanent student counsellors of faculties and others were temporary student counsellors of the faculties. Their experience in counselling is varied from less than 5 years to more than twenty-five years. 
Journal of the University Librarians Association of Sri Lanka, Vol.24, Issue 2, June 2021, 27-56 DOI: http://doi.org/

\section{Table 1}

Demographic Information of the Student Counselors

\begin{tabular}{|c|c|c|}
\hline \multirow[t]{2}{*}{ Factor } & \multirow[t]{2}{*}{ Category } & \multirow{2}{*}{$\begin{array}{l}\mathrm{N}=64 \\
\mathrm{n}=42\end{array}$} \\
\hline & & \\
\hline \multirow[t]{14}{*}{ Affiliated Faculty } & Arts & $\mathrm{N}=27$ \\
\hline & & $\mathrm{n}=19$ \\
\hline & Education & $\mathrm{N}=03$ \\
\hline & & $\mathrm{n}=02$ \\
\hline & Management & $\mathrm{N}=08$ \\
\hline & & $\mathrm{n}=05$ \\
\hline & Medicine & $\mathrm{N}=07$ \\
\hline & & $\mathrm{n}=01$ \\
\hline & Law & $\mathrm{N}=07$ \\
\hline & & $\mathrm{n}=04$ \\
\hline & Library & $\mathrm{N}=01$ \\
\hline & & $\mathrm{n}=01$ \\
\hline & Science & $\mathrm{N}=11$ \\
\hline & & $\mathrm{n}=10$ \\
\hline \multirow[t]{3}{*}{ Status as the counselor } & Senior & $\mathrm{n}=03$ \\
\hline & Permanent & $\mathrm{n}=04$ \\
\hline & Temporary & $\mathrm{n}=35$ \\
\hline \multirow[t]{4}{*}{ Experience in counseling } & 1 to 05 years & $\mathrm{n}=35$ \\
\hline & 05 to 15 years & $\mathrm{n}=05$ \\
\hline & 15 to 25 years & $\mathrm{n}=01$ \\
\hline & More than 25 years & $\mathrm{n}=01$ \\
\hline
\end{tabular}




\section{Research Question 1}

\section{What are Student Counsellors' Experiences in Different Student Issues and Counseling Methods?}

\section{Issues that Students Bring to University Student Counsellors.}

During the interviews, 42 student counsellors indicated that students brought to them issues such as difficulties in adjusting to university life, difficulties in motivation or decision-making, relationship difficulties with friends, families, partners, hostel mates, exam stress and anxiety, uncertainty about careers, and study directions, depression or loneliness or anxiety or grief, feeling suicidal and that life is not worth living, worrying about food, drinking or drug-taking behaviours, difficulties in making friends, communicating effectively with others and coping with illness or death of loved ones or students' illness.

\section{Figure 1}

\section{Students' Issues those were Brought to Student Counsellors}

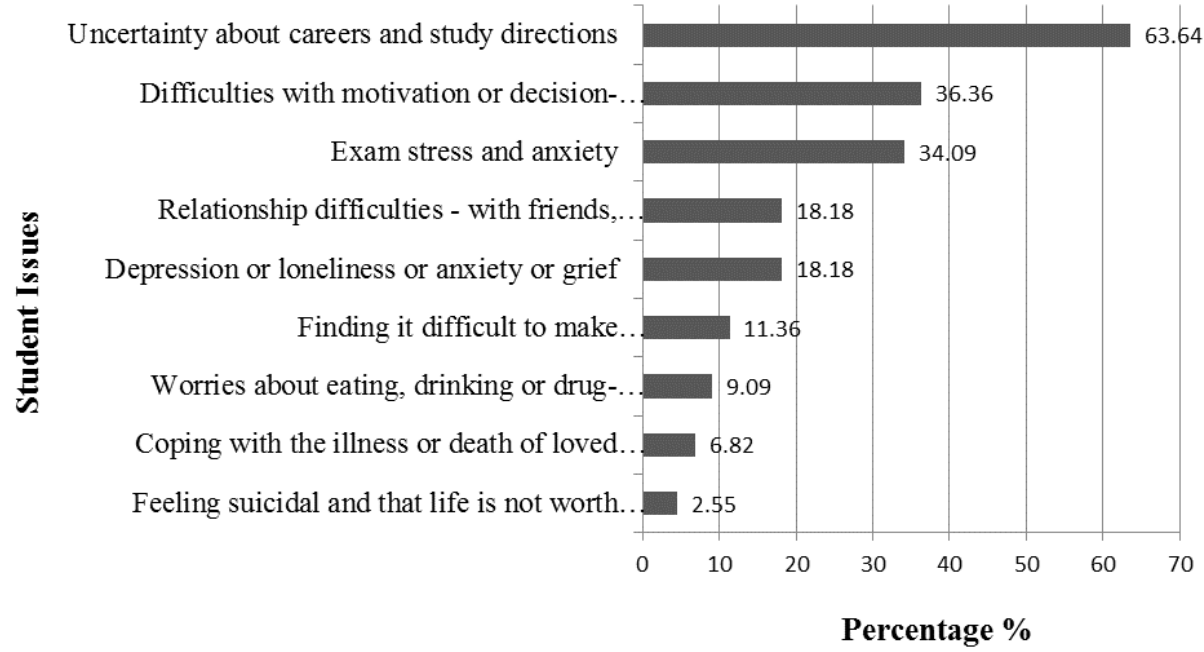


Uncertainty about careers and study directions (63.64\%), difficulties in motivation or decision making (36.36\%), and exam stress and anxiety (34.09\%) are the most prominent issues of university students while feeling suicidal and that life is not worth living is the least prominent issue among the students as depicts by the Figure 1 .

\section{Counselling Methods Pracitise by University Student}

Counsellors. All university student counsellors practice short-term individual counselling (100\%) methods to address student issues as shown in Figure 2.

\section{Figure 2}

Counselling Methods Practice by Student Counsellors

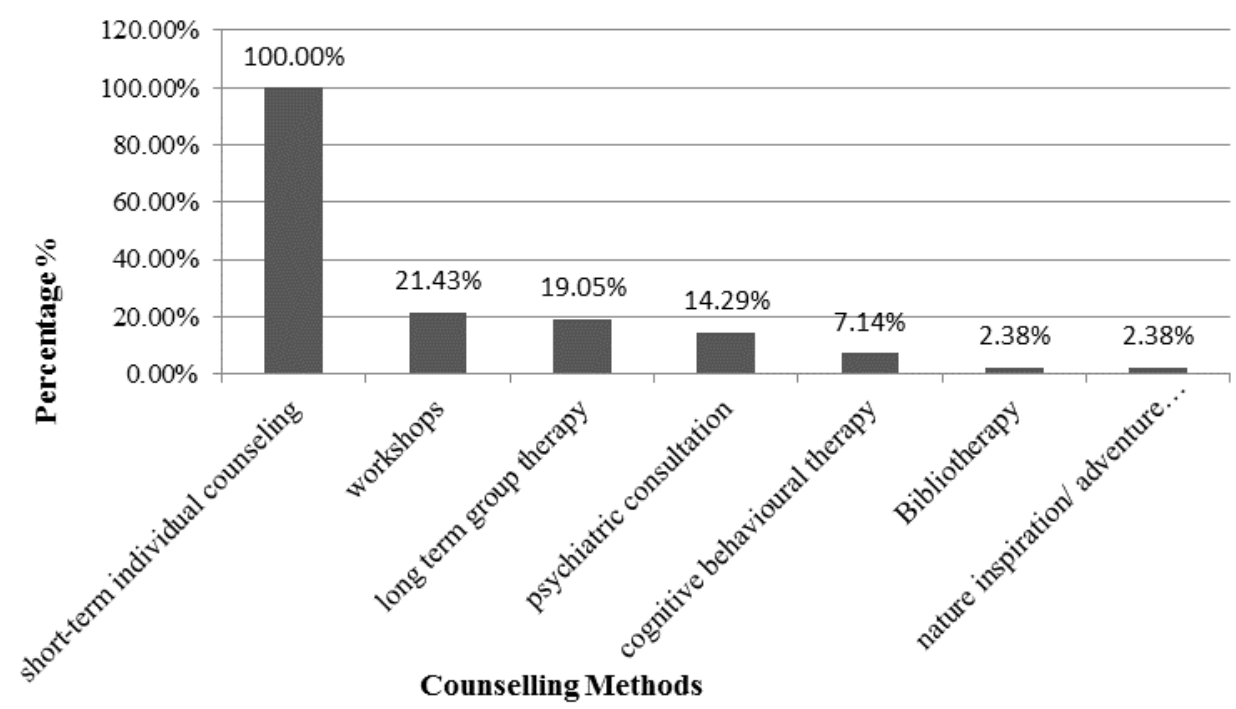

In addition, some of them conduct workshops for students (21.43\%), engage in long-term counselling for student groups (19.5\%), organize psychiatric consultation/treatment (14.29\%), cognitive behavioural therapy and nature inspiration activities (adventure bond). 
Only one counsellor practices the bibliotherapy technique as the counselling method using his private library. Further counselling of emotionally and mentally disturbed individuals and specialized counselling issues are directed to professional counsellors.

\section{Research Question 2}

\section{What is the Current Understanding of Student Counsellors on the} Bibliotherapy Technique?

Student counsellors use different techniques to address students' specific issues but the bibliotherapy technique is not much popular among them. As depicts in Table 2, from the total sample, only six counsellors (14.29\%) are aware of the bibliotherapy technique of counselling. They define the term 'bibliotherapy' in different ways: "Bibliotherapy is using books for healing psychiatric issues", "a therapeutic method bound with reading materials to address mental issues", "a healing method related to storytelling and reading to overcome specific issues", "therapy by books", and "using specific reading material to address specific issues". $85.71 \%$ of the student counsellors couldn't firmly define the term and didn't show a proper understanding of the method. Once they were explained the term and the method by the researcher, all the student counsellors show a positive attitude towards initiating such a service in the university. Some of them commented,"...eagerly waiting for commencing of the bibliotherapy service in the university to heal students who are stressed with educational, social and personal issues". 


\section{Table 2}

Student Counsellors' Awareness of Bibliotherapy as a Counselling Tool

\begin{tabular}{ccc}
\hline Options given & \multicolumn{2}{c}{$(N=42)$} \\
\cline { 2 - 3 } & $n$ & $\%$ \\
\hline $\begin{array}{c}\text { Can define 'bibliotherapy' and } \\
\text { understand the method }\end{array}$ & $\mathrm{n}=6$ & 14.29 \\
$\begin{array}{c}\text { Difficult to define 'bibliotherapy' and } \\
\text { can't understand the method }\end{array}$ & $\mathrm{n}=25$ & 59.52 \\
Not responded & $\mathrm{n}=11$ & 26.19 \\
\hline
\end{tabular}

\section{Research Question 3}

What is the Student Counsellors' Perception on Applying Bibliotherapy Service to Address Students' Issues?

As depicts in Table 3, student counsellors believe that bibliotherapy service can be implemented to overcome student issues such as 'difficulties with English language skills' (4.21), 'uncertainty about careers and study directions' (4.15), 'exam stress and anxiety' (3.97), and 'difficulties in motivation or decision-making'. According to the counsellors' view point bibliotherapy will be successful on students' specific issues such as study issues, social/life skills, and career issues but not on grief, trauma/loss, specific clinical diagnoses, and abuse. Therefore the least mean values show 'feeling suicidal and that life is not worth living' (1.62), 'worrying about food, drinking or drug-taking behaviours' (2.15), and 'relationship difficulties' (2.85). 


\section{Table 3}

Mean Ratings of Student Counsellors' Perception on Applying Bibliotherapy Service

\begin{tabular}{|c|c|c|c|}
\hline Purpose & $N$ & $M$ & SD \\
\hline $\begin{array}{l}\text { Coping with the illness or death of loved } \\
\text { ones or your own illness }\end{array}$ & 42 & 3.05 & 1.36 \\
\hline $\begin{array}{l}\text { Depression or loneliness or anxiety or } \\
\text { grief }\end{array}$ & 40 & 3.23 & 0.97 \\
\hline Difficulties in adjusting to university life & 38 & 3.05 & 0.72 \\
\hline Difficulties with English language skills & 42 & 4.21 & 0.89 \\
\hline $\begin{array}{l}\text { Difficulties in motivation or decision- } \\
\text { making }\end{array}$ & 41 & 3.95 & 0.65 \\
\hline Exam stress and anxiety & 41 & 3.97 & 0.67 \\
\hline $\begin{array}{l}\text { Feeling suicidal and that life is not worth } \\
\text { living }\end{array}$ & 39 & 1.62 & 0.63 \\
\hline $\begin{array}{l}\text { Finding it difficult to make } \\
\text { friends/communicate } \\
\text { effectively with others }\end{array}$ & 40 & 3.44 & 0.85 \\
\hline $\begin{array}{l}\text { Relationship difficulties with friends, } \\
\text { families, partners, hostel mates. }\end{array}$ & 38 & 2.85 & 0.67 \\
\hline $\begin{array}{l}\text { Uncertainty about careers and study } \\
\text { directions }\end{array}$ & 41 & 4.15 & 0.67 \\
\hline $\begin{array}{l}\text { Worrying about food, drinking or drug- } \\
\text { taking behaviours }\end{array}$ & 40 & 2.15 & 0.84 \\
\hline
\end{tabular}




\section{Research Question 4}

What are the Steps that can be Practised to Develop a Bibliotherapy Service in the University?

Student counsellors' view point on a suitable location to develop the bibliotherapy collection within the university, selecting material for the bibliotherapy service, types of material to be included in the collection, and practicing methods of bibliotherapy service are identified.

A Place to Develop the Collection. Identifying a proper place or a platform is very important to initiate the bibliotherapy service. Figure 3 and Table 4 depict the selection of the most suitable place according to the student counsellors.

\section{Figure 3}

The Place to Develop the Bibliotherapy Collection

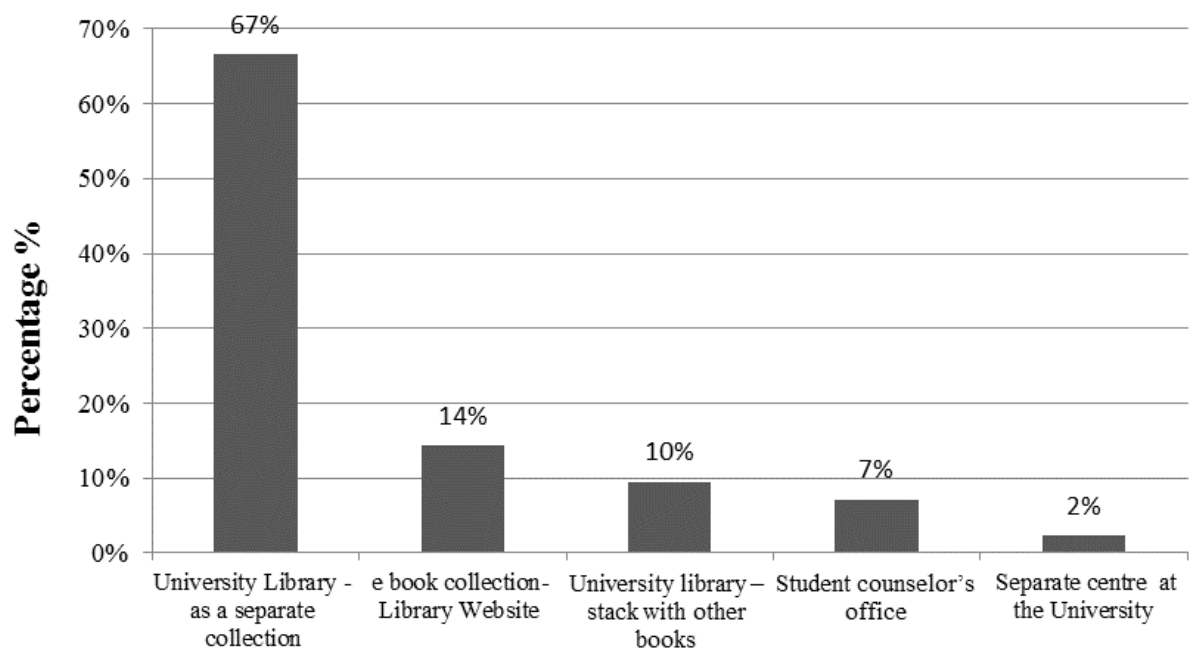

Place for the Location 
The majority of the counsellors (67\%) identified the university library as the most suitable place for the bibliotherapy collection. They suggested building up a collection as a separate collection in the library. According to them: "library is the only public place in the university that accommodates all the university students, without any restrictions. At the same time knowingly or unknowingly, at present, the library is already engaged in this service. Then it is easy to develop a separate collection in the university library, specifically for the bibliotherapy service with minimum effort". The second choice was different from the first choice with a suggestion of building a virtual collection on a digital platform $(14 \%)$. One of the student counsellors of the Faculty of Science commented "if a student has a specific psychiatric issue, normally he/she avoid public places such as libraries. Therefore the best method is to buildup a digital collection with access facilities from the Library website". Use the university library but stack the selected books among other library books, having a separate centre in the university and have a collection at the student counselors' office are among other suggestions.

\section{Method of Selecting/Recommending Books for the Collection.}

The main selection criteria for identifying reading materials for the bibliotherapy collection are 'read the book by counsellors' (4.12) followed by 'peer recommendations' (3.64), 'recommendations made by librarians' (3.08), 'book reviews' (3.0), and student recommendations as shown in Table 4. Most of the counselors commented that "reading book by the counsellor before recommending for the collection is important because it is difficult to get an exact picture of the content of the book without reading and it is really important to select the right book for the right person". 
Practising Methods of Bibliotherapy. According to the mean values of different bibliotherapy practicing methods indicated in Table 4, these student counsellors identified 'independent reading by students' (4.4) as the best method followed by 'conduct classroom/guidance sessions' (4.28) and 'group therapy reading' (4.08).

\section{Table 4}

Mean Ratings for Main Consider on Collection Development

\begin{tabular}{lrrr}
\hline & $\mathrm{N}$ & $\mathrm{M}$ & $\mathrm{SD}$ \\
\hline Suitable place for the collection & & & \\
$\quad$ University Library as a separate collection & 41 & 4.4 & 0.71 \\
E-book collection Library Website & 42 & 3.56 & 0.93 \\
University library stack with other books & 41 & 2.75 & 0.61 \\
Student counsellor's office & 40 & 2.48 & 0.95 \\
Separate centre at the university & 38 & 1.96 & 1.24 \\
Selecting books for the collection & & & \\
Read the book by the counsellor & 39 & 4.12 & 0.97 \\
Peer recommendations & 39 & 3.64 & 0.86 \\
Librarians & 42 & 3.08 & 0.86 \\
Book reviews & 41 & 3.0 & 0.76 \\
Student recommendations & 42 & 2.98 & 0.82 \\
Practising methods of bibliotherapy & & & \\
Independent reading by student & 41 & 4.4 & 0.71 \\
Conduct classroom/guidance units & 40 & 4.28 & 0.68 \\
group therapy reading & 40 & 4.08 & 0.81 \\
Read to students or read with students & 38 & 3.12 & 0.88 \\
Employed drama activities in conjunction with & 37 & 2.72 & 0.68 \\
reading & & & \\
Reading with accompanying art activities & 38 & 2.4 & 0.87 \\
Students read to their peers & 40 & 2.36 & 0.76 \\
Accompanied reading with writing & 39 & 2.32 & 0.95 \\
\hline
\end{tabular}


One of the student counsellors of the Faculty of Medicine commented "bibliotherapy is not only reading books but it is closely associated with storytelling based on books as practiced from the childhood". Reading accompanied with drama activities (2.72), art activities (2.4), and writing activities (2.32) are also among the suggested practicing methods but with low mean ratings as depicted in Table 4.

Categorizing the Bibliotherapy Collection. Student counsellors suggest basic reading materials for the collection to contain self-help materials, fiction, non-fiction, work books, poetry, audio books, audiovisual books, and e-books. Further, they can be categorized under different sub headings as shown in Figure 4. As depicted in Table 5 the highest weighted percentage was for the 'language skills (100\%), followed by 'positive psychology' (95.24\%), 'confidence building' (95.24\%), and 'study and presentation skills (95.24\%).

\section{Figure 4}

\section{Popular Subheadings for the Bibliotherapy Collection}

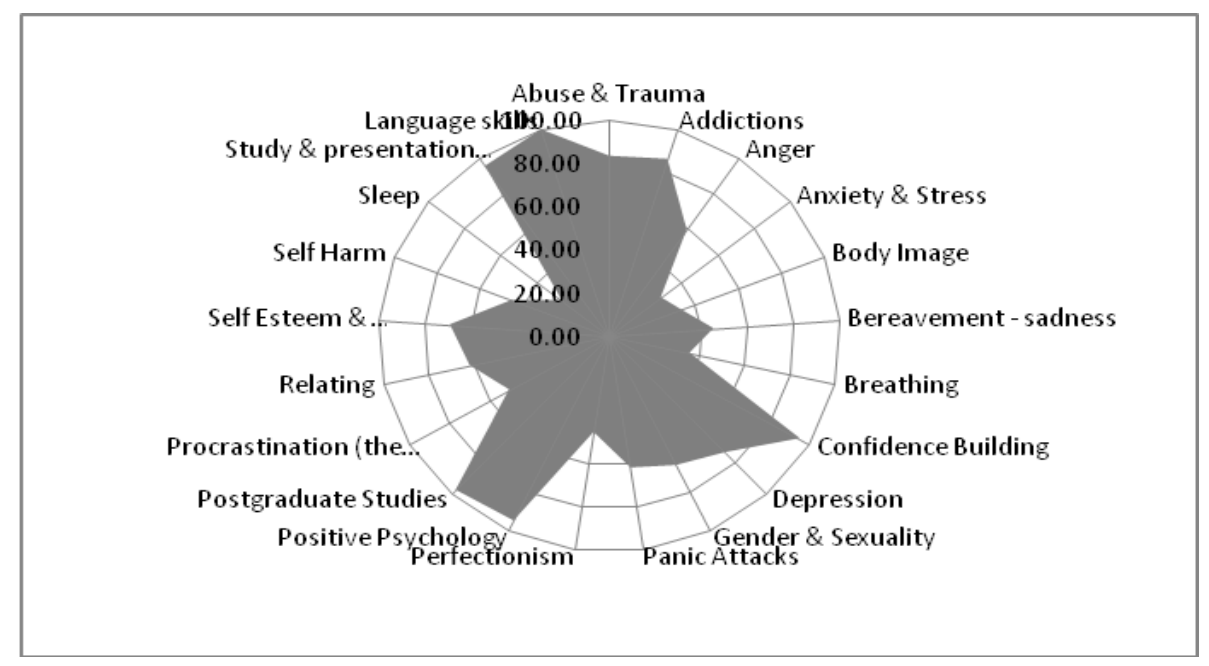


Journal of the University Librarians Association of Sri Lanka, Vol.24, Issue 2, June 2021, 27-56

DOI: http://doi.org/

\section{Table 5}

Weighted Percentage of Popular Subheadings for the Collection

\begin{tabular}{lcclcc}
\hline \multicolumn{1}{c}{ Word } & Count & Weighted \% & Word & Count & Weighted \% \\
\hline Language skills & 42 & 100.00 & Panic Attacks & 26 & 61.90 \\
Confidence building & 40 & 95.24 & Relating & 26 & 61.90 \\
Positive Psychology & 40 & 95.24 & Anger & 25 & 59.52 \\
Study \& presentation skills & 40 & 95.24 & Procrastination (the action of delaying/ & 21 & 50.00 \\
& & & opostponing something) & & \\
Addictions & 36 & 85.71 & Grief/ sadness & 19 & 45.24 \\
Abuse \& trauma & 35 & 83.33 & Perfectionism & 19 & 45.24 \\
Motivation & 35 & 83.33 & Self Harm & 19 & 45.24 \\
Postgraduate Studies & 35 & 83.33 & Breathing/ yoga & 15 & 35.71 \\
Religious books & 35 & 83.33 & Body Image & 14 & 33.33 \\
Depression & 31 & 73.81 & Anxiety \& stress & 12 & 28.57 \\
Self esteem \& assertiveness & 29 & 69.05 & Sleep & 11 & 26.19 \\
Gender \& sexuality & 28 & 66.67 & & & \\
\hline
\end{tabular}




\section{Research Question 5}

What are the Benefits of the Bibliotherapy Service for University Students?

All the counselors believe university students will be benefited from bibliotherapeutic services in the university, if implemented. As Table 6 depicts the most benefited attribute is 'acquisition of knowledge about diverse people, culture, situations, abilities, experiences, and perspectives' (4.4), followed by 'improving English language skills' (4.28) and 'support for academic activities: presentations and managing exam stress' (4.04). The least benefited attribute is 'cope with fears and sensitive topics, such as crime, dying, nightmares, suicide, crises, natural disasters, and terrorist attacks' and mean value is 1.76 .

\section{Table 6}

Mean Ratings of Expected Benefits of Bibliotherapy Service

\begin{tabular}{|c|c|c|c|}
\hline Expected benefits of bibliotherapy & $\mathrm{N}$ & M & SD \\
\hline $\begin{array}{l}\text { Acquisition of knowledge for diverse people, } \\
\text { culture, situations, abilities, } \\
\text { experiences, and perspectives }\end{array}$ & 41 & 4.4 & 0.71 \\
\hline Improve English language skills & 41 & 4.28 & 0.68 \\
\hline $\begin{array}{l}\text { Give academic experiences: giving } \\
\text { presentations, managing exam stress }\end{array}$ & 40 & 4.04 & 0.93 \\
\hline Coping with life away from home & 41 & 3.56 & 0.77 \\
\hline $\begin{array}{l}\text { To overcome issues associated with being a } \\
\text { member of a minority group or } \\
\text { groups (lesbian, bisexual, gay, and } \\
\text { transgendered (LBGT)) }\end{array}$ & 37 & 3.56 & 1.33 \\
\hline
\end{tabular}




\begin{tabular}{lccc}
\hline \multicolumn{1}{c}{ Expected benefits of bibliotherapy } & $\mathrm{N}$ & $\mathrm{M}$ & $\mathrm{SD}$ \\
\hline Career guidance & 42 & 3.12 & 0.78 \\
Improve self-understanding and self-esteem & 42 & 3.08 & 0.86 \\
Path to higher studies & 38 & 2.8 & 0.71 \\
Building self-confidence and assertiveness & 39 & 2.72 & 0.79 \\
To overcome depression, anxiety, and panic & 40 & 2.48 & 0.71 \\
To cope with fears and sensitive topics, such & 41 & 1.76 & 0.97 \\
$\quad$ as crime, dying, nightmares, suicide, & & & \\
$\quad$ crises, natural disasters, and terrorist & & & \\
$\quad$ attacks & & & \\
\hline
\end{tabular}

\section{Benefited Student Group on Gender Basis}

The majority of the student counsellors (61.90\%) indicate that both males and females are equally benefited from the bibliotherapy service as shown in Table 7.

\section{Table 7}

Benefited Student Group on Gender Basis

\begin{tabular}{lcc}
\hline \multicolumn{1}{c}{ Gender } & $(N=42)$ & $\%$ \\
\cline { 2 - 3 } & $n$ & 11.90 \\
Male Students & $\mathrm{n}=05$ & 23.81 \\
Female students & $\mathrm{n}=10$ & 61.90 \\
Both males and females & $\mathrm{n}=26$ & 2.38 \\
Not responded & $\mathrm{n}=01$ & \\
\hline
\end{tabular}

Some student counsellors $(23.81 \%)$ identify females as the more benefited group over males because they are more sensitive and reluctant 
to discuss their problems with peers and counsellors. One counsellor commented, "it should be males because males tend to be more introverted and they tend to find solutions/answers to their problems by themselves without discussing them with others". According to him books can provide answers for their problems.

\section{Research Question 6}

\section{What are the Possible Challenges When Implementing the} Bibliotherapy Service in the University Environment?

Implementing bibliotherapy service in the university environment is not an easy task as commented by most of the student counsellors due to various reasons. Selection of books for the collection, obtain continuous professional guidance and support to build up the collection, difficulties in addressing all the possible issues face by students from this technique, the reluctance of students for reading books are some of the main challenges of bibliotherapy service. Maintain continuous collaboration between the library and the student counsellors when developing the collection, identifying funding sources and donors to purchase relevant material, and approvals of higher authorities of the university to implement bibliotherapy service are also identified as challenges to be addressed. As this is a new service to the students, it is also a challenge to promote this service among students of the university. 


\section{Conclusion and Recommendations}

\section{Conclusion}

Among the different issues that students bring to the student counsellors, uncertainty about careers and study directions, difficulties in motivation or decision-making, and exam stress and anxiety are the most prominent issues. Student counsellors practice short-term individual counseling as the counseling method except for one who practices bibliotherapy when solving students' issues. They believe that bibliotherapy service will help university students to overcome some of their issues such as education/language, social/life skills, and career issues but not issues related to grief, trauma/loss, specific clinical diagnoses, and abuse. When selecting reading materials for the bibliotherapy collection 'read the book by counsellors', 'base on peer recommendations', 'book reviews' were the preferred criteria, and 'recommendations made by librarians' were also considered. University library was identified as the most suitable place to establish the bibliotherapy services and self-help materials, work books, poetry, fiction, non-fiction, audio books, and audiovisual books were the suggested material types. The majority of the counsellors identified the university library as the most suitable place for the bibliotherapy collection followed by a web-based digital platform for e-books. Results reveal that all the student counsellors believe university students will be benefited from bibliotherapy services in the university, if implemented and students will be more benefited in areas such as 'acquisition of knowledge about diverse people, culture, situations, abilities, experiences, and perspectives', 'improving English language skills' and 'support for academic activities: presentations and managing exam stress'. There may 
be numerous challenges when trying to develop this service and need to have a proper plan approved by the higher authorities of the university to achieve the success of the bibliotherapy service.

\section{Limitations of the Study}

This study is limited only to the student counsellors' perception of initiating bibliotherapy service in the University of Colombo. Surveying students' perceptions, as well as the librarians' perceptions on bibliotherapy, may be needed to come up with a comprehensive picture of this service. Explaining the survey questions and the basic concept of bibliotherapy to each participant of the survey also grabs a considerable amount of time.

\section{Recommendations}

While retaining the basic concept of bibliotherapy, it is essential to discover new avenues of introducing this service for the Net Generation students who are reluctant to read books. Accompanying outbound activities and nature-inspired activities along with bibliotherapy and introducing video therapy, song therapy, and other new therapeutic methods on a digital platform should be considered to achieve the targeted success.

It will be useful to incorporate active participation of librarians in implementing the bibliotherapy services in universities by facilitating space to develop the collection and involving in the material selection process and assisting students to identify reading materials. Further librarians can identify the students' psychological issues and can refer them to a professional counsellor for further assistance. Continuous support and guidance of professional counsellors would be important in 
each step of developing and implementing bibliotherapy service in the university environment. During the process of initiating the bibliotherapy service in the university environment, reccomendations from student counsellors could be used as a basis to identify this service as a requirement at the university level and to attract administration support. Further, this study opens up new avenues for future studies on bibliotherapy and related topics, librarians' perception of developing a bibliotherapy collection, students' perception of initiating and practicing bibliotherapy services in the university environment, and also novel methods related to bibliotherapy that can be introduced to Net Generation students of universities, who are reluctant to read books physically. 


\section{References}

Arulanantham, S., \& Navaneethakrishnan, S. (2014a). Bibliotherapy in Sri Lankan higher education system: Implications for university libraries. Sri Lanka Library Association. http://repo.lib.jfn.ac.lk/ ujrr/handle/123456789/774

Arulanantham, S., \& Navaneethakrishnan, S. (2014b). Introducing bibliotherapy in public libraries of Jaffna district: An exploratory study. Journal of the University Librarians Association of Sri Lanka, 17(2), 104-118. http://dx.doi.org/10.4038/jula.v17i2.6648

Crothers, S. M. (1916). A literary clinic. Atlantic Monthly, 118, 291-301. https://www.unz.com/print/AtlanticMonthly-1916sep-00291

Crumley, E. T. (2006). Exploring the roles of librarians and health care professionals involved with complementary and alternative medicine. Journal of Medical Library Association 94(1), 81-89. https://www.ncbi.nlm.nih.gov/pmc/articles/PMC1324776/

Forrest, M. E. S. (1998). Recent developments in reading therapy: A review of the literature. Health Library Review. 15, 157-164. https://onlinelibrary.wiley.com/doi/epdf/10.1046/j.13652532.1998.1530157.x

Harris, T. L., \& Hodges, R. E. (Eds.). (1995). The literacy dictionary: The vocabulary of reading and writing. International Reading Association.

Heath, M. A., Sheen, D., Leavy, D., Young, E. L., \& Money, K. (2005). Bibliotherapy: A resource to facilitate emotional healing and growth. School Psychology International. 26, 563-580. https://doi.org/10.1177/0143034305060792 
McMillen, P. S., \& Pehrsson, D. (2004). Specialty of the house: Bibliotherapy for hospital patients. Journal of Hospital Librarianship, 4(1), 73-82. https://doi.org/10.1300/ J186v04n01_07

Ogrenir, B. (2013). Teachers' adequacy in applications of bibliotherapy in classrooms. In Proceedings of WEI International Academic Conference Proceeding (pp. 40-41). The West East Institute. https://www.westeastinstitute.com/wp-content/uploads/2013/02/ ANT13-242-Burcin-Ogrenir.pdf

Pardeck, J. T., \& Pardeck, J. A. (1998). An exploration of the uses of children's books as an approach for enhancing cultural diversity. Early Child Development and Care, 147(1), 25-31. https://doi.org/10.1080/0300443981470104

Premarathne, B. N. G. S. (2016). Bibliotherapy as a tool for reducing the study behavior issues among undergraduates: A case study at the University of Peradeniya. In Proceedings of $1^{\text {st }}$ International Conference on Library and Information Management (p. 86). http://repository.kln.ac.lk/handle/123456789/14985

Riahinia, N., \& Azimi, A. (2007). Bibliography usage and practice: A study through Tehran's Academic Counselling Centres. Library Herald. 45, 70-83. https://www.indianjournals.com/ ijor .aspx?target $=$ ijor:lh $\&$ volume $=45 \&$ issue $=1 \&$ article $=008$

Riahinia, N., \& Azimi, A. (2011). Librarians' participation in bibliotherapy treatment of distressed students. Interdisciplinary Journal of Contemporary Research in Business. 3(6), 709-721. https://www.researchgate.net/publication/322294166 
Journal of the University Librarians Association of Sri Lanka, Vol.24, Issue 2, June 2021, 27-56 DOI: http://doi.org/

Sheih, S. M. C., \& Hunng, H. J. (2013). A study on undergraduate demand for developmental bibliotherapeutic service in university libraries. Journal of Library and Information Science Research. $8(1), \quad$ 62-68. http://morris.lis.ntu.edu.tw/jlisr/images/pdf/v8/ 8-1-2\%20English\%20Abstract.pdf 